\title{
Sumber Sebagai Hara Pengganti AB mix pada Budidaya Sayuran Daun Secara Hidroponik
}

\author{
Sources as Subtitute of AB nutrient Solution Mix for Hydroponics of Leafy Vegetables
}

Rizqi Utami Nugraha ${ }^{1}$, dan Anas Dinurrohman Susila ${ }^{{ }^{*}}$

Diterima 5 Desember 2014/Disetujui 2 Maret 2015

\begin{abstract}
Increasing in fertilizer price has caused increase in hydroponic system cost. The objective of the research was to determine the best fertilizer source that could replace $A B$ mix by examining several sources of nutrients, i.e. NPK 15:15:15, NPK 12:14:12 for hydroponic cultivation of spinach, pakchoy, and lettuce. The research was conducted in the Green House Dramaga Field Unit, University Farm, IPB Bogor from February to April 2013. The treatments (AB mix, NPK 15:15:15, and NPK 12:14:12) were arranged in randomized completely blok design with 4 replications. The results showed that fertilizer treatments used did not affect the vegetative growth of spinach, pakchoy, and lettuce, but AB mix fertilizer treatment gave the highest yield in spinach plants, pakchoy, and lettuce in yield components i.e. an average weight/plant and weight of marketable yield, respectively at $21.65 \mathrm{~g}, 235.75 \mathrm{~g}$ spinach, $46.06 \mathrm{~g}, 465.75 \mathrm{~g}$ pakchoy, and $25.93 \mathrm{~g}$ lettuce. In lettuce experiment, no marketable yield was obtained. Based on these results NPK 15:15:15 and NPK 12:14:12 fertilizer could not replace AB mix as a source of plant nutrients in spinach, pakchoy, and hydroponic lettuce.
\end{abstract}

Key words: AB mix, hydroponic, leafy vegetables , NPK 15:15:15, NPK 12:14:12

\begin{abstract}
ABSTRAK
Kenaikan harga pupuk menyebabkan kenaikan biaya dalam sistem hidroponik. Penelitian ini bertujuan untuk mendapatkan hara yang dapat menggantikan $\mathrm{AB}$ mix dengan cara menguji beberapa sumber hara, yaitu NPK 15:15:15, NPK 12:14:12 pada budidaya bayam, pakchoy, dan selada secara hidroponik. Percobaan dilaksanakan di Green House Unit Lapangan Dramaga, University Farm, IPB Dramaga Bogor, dari Februari sampai April 2013. Rancangan percobaan yang digunakan adalah Rancangan Kelompok Lengkap Teracak dengan menggunakan tiga perlakuan: AB mix, NPK 15:15:15, dan NPK 12:14:12 dengan 4 ulangan. Hasil penelitian menunjukkan bahwa pupuk tidak mempengaruhi pertumbuhan vegetatif tanaman bayam, pakchoy, dan selada, tetapi perlakuan pupuk $\mathrm{AB}$ mix memberikan hasil produksi tertinggi pada tanaman bayam, pakchoy, dan selada yaitu pada komponen hasil panen rata-rata bobot $\operatorname{tanaman}^{-1}$ dan bobot layak pasar, berturutturut sebesar $21.65 \mathrm{~g}, 235.75 \mathrm{~g}$ tanaman bayam, $46.06 \mathrm{~g}, 465.75 \mathrm{~g}$ tanaman pakchoy dan $25.93 \mathrm{~g}$ tanaman selada. Pada percobaan selada tidak diperoleh hasil yang dapat dipasarkan. Berdasarkan hasil penelitian tersebut pupuk NPK 15:15:15 dan NPK 12:14:12 tidak dapat menggantikan pupuk AB mix sebagai sumber hara pada tanaman bayam, pakchoy, dan selada secara hidroponik.
\end{abstract}

Kata kunci: AB mix, hidroponik, sayuran daun, NPK 15:15:15, NPK 12:14:12

\section{PENDAHULUAN}

Sayuran merupakan salah satu produk pertanian yang banyak dikonsumsi oleh masyarakat pedesaan ataupun perkotaan. Pertambahan penduduk dan konsumsi per kapita menyebabkan kebutuhan sayuran mengalami peningkatan. Berdasarkan data

${ }^{1}$ Departemen Agronomi dan Hortikultura, Fakultas Pertanian, Institut Pertanian Bogor

(Bogor Agricultural University), Jl. Meranti, Kampus IPB Darmaga, Bogor 16680, Indonesia

Telp.\&Faks.62-251-8629353.*Email korespondensi: anasdsusila10@ gmail.com 
BPS tahun (2012) produksi sayuran nasional meningkat pada tahun 2011 dari tahun sebelumnya yakni sebesar 695,471 ton. Menurut Direktorat Jenderal Hortikultura (2009) konsumsi sayuran penduduk Indonesia pada tahun 2009 baru mencapai 43.5 $\mathrm{kg} / \mathrm{kapita} / \mathrm{tahun}$, angka tersebut jauh di bawah standar konsumsi sayur yang direkomendasikan oleh Food and Agriculture Organization (FAO), yaitu sebesar $73 \mathrm{~kg} / \mathrm{kapita} / \mathrm{tahun}$. Oleh karena itu, untuk memenuhi tingkat konsumsi sayuran nasional perlu diimbangi dengan peningkatan produksi sayuran yang berkualitas.

Sistem budidaya sayuran yang dilakukan masyarakat Indonesia umumnya secara konvensional. Upaya peningkatan produktivitas dan kualitas sayuran secara konvensional telah banyak dilakukan oleh petani meskipun hasilnya kurang memuaskan. Hidroponik merupakan salah satu sistem budidaya pertanian yang digunakan untuk memperbaiki kualitas sayuran yang dihasilkan. Hidroponik dapat didefinisikan sebagai sistem budidaya tanaman dengan menggunakan media selain tanah, tetapi mengunakan media bersifat inert seperti kerikil, pasir, gambut, vermikulit, batu apung atau serbuk gergaji dan ditambahkan larutan hara yang berisi seluruh unsur yang dibutuhkan bagi pertumbuhan tanaman (Resh, 2004). Menurut Parks dan Murray (2011), dalam sistem budidaya secara hidroponik perlu diberikan larutan nutrisi yang cukup, air, dan oksigen pada perakaran tanaman agar pertumbuhan tanaman baik. Toshiki (2012) menyatakan bahwa di antara faktor-faktor yang mempengaruhi sistem produksi tanaman secara hidroponik, larutan nutrisi menjadi salah satu faktor penentu yang paling penting dalam menentukan hasil dan kualitas tanaman.

Budidaya sayuran daun secara hidroponik umumnya menggunakan larutan hara berupa larutan hidroponik standar ( $\mathrm{AB}$ mix). Permasalahannya pada saat ini penggunaan larutan hara $\mathrm{AB}$ mix memerlukan biaya yang relatif tinggi. Masyarakat umum memandang bahwa teknologi secara hidroponik memiliki nilai ekonomi yang cukup besar dalam hal perawatan dan harga pupuk. Alternatif dalam pengembangan teknologi hidroponik sangat diperlukan agar mempermudah masyarakat khususnya petani kecil dalam menerapkan budidaya sayuran, yaitu dengan cara memanfaatkan beberapa sumber hara dengan harga yang relatif lebih murah. Ramadiani dan Susila (2014) menyimpulkan bahwa pupuk majemuk NPK 15:15:15 dengan konsentrasi $\mathrm{N}$ yang disetarakan dengan larutan hara $\mathrm{AB}$ mix dapat digunakan pada budidaya kangkung, caisin, dan kailan secara hidroponik. Penelitian ini bertujuan untuk mendapatkan hara yang dapat menggantikan $\mathrm{AB}$ mix dengan cara menguji beberapa sumber hara : NPK 15:15:15, dan NPK 12:14:12 dengan penyetaraan konsentrasi $\mathrm{N}$ terhadap $\mathrm{AB}$ mix pada budidaya bayam (Amaranthus L), selada (Lactuca sativa L), dan pakcoy (Brassica rapa cv pakchoy) secara hidoponik.

\section{BAHAN DAN METODE}

Penelitian dilaksanakan mulai Februari sampai dengan April 2013. Kegiatan penelitian dilaksanakan pada dua tempat, yaitu: di Green House Unit Lapangan Dramaga, University Farm IPB, dengan ketinggian tempat $250 \mathrm{~m}$ di atas permukaan laut dengan titik koordinat 6033'5.68" LS, $106^{\circ} 42^{\prime} 51.33^{\prime}$ " BT dan Laboratorium Pascapanen IPB, Dramaga, Bogor. Bahan utama yang digunakan dalam penelitian ini adalah benih selada varietas Belini, pakcoy varietas Nauli, bayam varietas amaranth Alabama, pupuk kascing, larutan hara hidroponik standar $\mathrm{AB}$ mix, pupuk NPK (15:15:15), pupuk NPK (12:14:12), insektisida berbahan aktif carbofuran, deltametrin, dan arang sekam.

Percobaan dilakukan dengan menggunakan Rancangan Kelompok Lengkap Teracak (RKLT) satu faktor. Rancangan ini terdiri dari tiga taraf perlakuan, yaitu $\mathrm{P0}=$ Kontrol (Pupuk AB mix) dengan dosis $300 \mathrm{ml} \mathrm{polibag}^{-1}$, P1 = Pupuk NPK (15:15:15) dengan penyetaraan unsur $\mathrm{N}$ dengan dosis $300 \mathrm{ml} \mathrm{polibag}^{-1}, \mathrm{P} 2=$ Pupuk NPK (12:14:12) dengan penyetaraan unsur $\mathrm{N}$ dengan dosis $300 \mathrm{ml} \mathrm{polibag}^{-1}$. Setiap jenis sayuran merupakan percobaan yang terpisah diberi 3 perlakuan. Perlakuan diulang sabanyak 4 ulangan sehingga terdapat 12 satuan percobaan, setiap satu satuan percobaan terdiri atas 3 polibag yang berisi 4 tanaman polibag $^{-1}$, sehingga total jumlah satu jenis tanaman yang ditanam sebanyak 144 tanaman. Jenis sayuran yang ditanam terdiri atas 3 jenis, sehingga total tanaman yang ditanam sebanyak 432 tanaman. Pengamatan dipilih secara acak 
dengan memilih 3 tanaman contoh dalam satuan percobaan, jumlah tanaman sampel sebanyak 36 tanaman untuk setiap komoditas, sehingga total tanaman sample sebanyak 108 tanaman. Apabila analisis ragam untuk perlakuan pemupukan menunjukkan pengaruh nyata, dilakukan uji lanjut DMRT dengan taraf nyata $5 \%$.

Pelaksanaan kegiatan meliputi sterilisasi rumah kaca, persiapan alat dan bahan. Proses penyemaian benih dilakukan dalam tray semai selama 21 hari atau setelah muncul 3-4 helai daun dari masing-masing tanaman dengan menggunakan media tanam kascing. Pindah tanam dari persemaian dilakukan ke dalam polibag $(40 \mathrm{~cm} \times 40 \mathrm{~cm})$ dengan menggunakan media tanam arang sekam, setiap polibag ditanami 4 bibit untuk setiap komoditas. Pembuatan pupuk $\mathrm{AB}$ mix dilarutkan dalam kontainer A (larutan hara stok A) dan kontainer B (larutan hara stok B) volume masing-masing $90 \mathrm{~L}$. Sebanyak $250 \mathrm{~mL}$ masingmasing larutan stok, diencerkan pada kontainer besar berukuran 120 L. Kemudian dilakukan pengukuran EC antara 1.5-2.5 mS dan nilai $\mathrm{pH}$ 5.5-6.5. Pupuk NPK (15:15:15), dan pupuk NPK (12:14:12), dilarutkan secara terpisah dengan penyetaraan konsentrasi $\mathrm{N}$ pada larutan $\mathrm{AB}$ mix $\left(180 \mathrm{mg} \mathrm{L}^{-1} \mathrm{~N}\right)$. Setelah disetarakan akan didapatkan pupuk NPK (15:15:15) sebanyak $1.2 \mathrm{~g} \mathrm{~L}^{-1}$, dan NPK (12:14:12) sebanyak $1.5 \mathrm{~g}$ $\mathrm{L}^{-1}$. Proses penyiraman dan pemupukan untuk larutan AB mix, NPK (15:15:15), dan NPK (12:14:12), dilakukan secara bersamaan dengan sistem fertigasi manual. Aplikasi dilakukan satu kali pada pagi hari disiramkan pada masingmasing media sebanyak $300 \mathrm{ml}$ polibag $^{-1}$. Proses pemanenan dilakukan pada tanaman bayam berumur 17 HST (Hari Setelah Tanam), pakcoy berumur $30 \mathrm{HST}$, dan selada berumur 32 HST.

Pengamatan dilakukan seminggu satu kali diukur dari 1 HST (hari setelah tanam) sampai dengan menjelang panen. Peubahpeubah yang diamati meliputi bagian vegetatif tanaman adalah sebagai berikut : tinggi tanaman, jumlah daun, lebar daun, panjang daun, diameter batang. Peubah-peubah yang diamati pada saat pasca panen adalah sebagai berikut : bobot daun, bobot batang, bobot akar, skor warna daun, bobot layak pasar, bobot tidak layak pasar, bobot per tanaman, bobot per 4 tanaman dan bobot total.

\section{HASIL DAN PEMBAHASAN}

\section{Bayam (Amaranthus L) Tinggi Tanaman dan Diameter Batang}

Tabel 1 menunjukkan bahwa perlakuan jenis sumber hara tidak berpengaruh nyata terhadap tinggi tanaman dan diameter batang. Pengaruh sangat nyata terlihat pada diameter batang tanaman bayam 2 MST (Minggu Setelah Tanam). Perlakuan pupuk AB mix pada 2 MST menghasilkan diameter batang paling besar dibandingkan diameter batang pada perlakuan pupuk NPK 15:15:15 dan NPK 12:14:12. Hal ini sesuai dengan penelitian Iqbal (2006) pemberian komposisi hara yang seimbang dapat diserap tanaman secara efektif serta menghasilkan daun yang lebar, dan diameter batang yang lebih besar.

\section{Jumlah Daun, Lebar Daun, Panjang Daun}

Perlakuan pemupukan tidak memberikan pengaruh nyata terhadap jumlah daun, lebar daun, dan panjang daun tanaman bayam kecuali, pada jumlah daun umur 2 MST (Tabel 2). Perlakuan pupuk $A B$ mix berbeda nyata dan menghasilkan jumlah daun lebih tinggi dibandingkan dengan perlakuan pupuk NPK 15:15:15.

Tabel 1. Pengaruh perlakuan jenis hara terhadap tinggi tanaman dan diameter batang tanaman bayam

\begin{tabular}{|c|c|c|}
\hline \multirow{3}{*}{ Perlakuan } & \multicolumn{2}{|c|}{ Umur Tanaman } \\
\hline & $1(\mathrm{MST})$ & 2(MST) \\
\hline & \multicolumn{2}{|c|}{ Tinggi Tanaman $(\mathrm{cm})$} \\
\hline $\mathrm{AB}$ mix & 9.21 & 19.73 \\
\hline NPK 15:15:15 & 9.13 & 19.58 \\
\hline NPK 12:14:12 & 9.01 & 19.5 \\
\hline \multirow{2}{*}{ Uji F } & tn & tn \\
\hline & \multicolumn{2}{|c|}{ Diameter Batang $(\mathrm{cm})^{a}$} \\
\hline AB mix & 0.35 & $0.70 \mathrm{a}$ \\
\hline NPK 15:15:15 & 0.29 & $0.57 \mathrm{~b}$ \\
\hline NPK 12:14:12 & 0.32 & $0.59 \mathrm{~b}$ \\
\hline Uji F & tn & $* *$ \\
\hline \multicolumn{3}{|c|}{$\begin{aligned} & \text { Keterangan: }(* *) \text { berpengaruh sangat nyata pada taraf } \\
& \text { uji } 1 \% ;(\text { tn) tidak berpengaruh nyata pada } \\
& \text { taraf uji } 5 \% \text {; angka-angka yang diikuti } \\
& \text { huruf yang sama pada kolom yang sama } \\
& \text { tidak berbeda nyata menurut uji DMRT } \\
& 5 \%, \text { MST = Minggu setelah tanam }\end{aligned}$} \\
\hline
\end{tabular}




\section{Skor Warna Daun, Bobot Daun, Bobot Batang, Bobot Akar}

Perlakuan tiga jenis sumber hara berpengaruh nyata terhadap skor warna daun dan bobot daun tanaman bayam (Tabel 3). Perlakuan NPK 12:14:12 menghasilkan skor warna daun yang lebih tinggi. Skor warna daun menunjukkan bahwa daun dengan perlakuan NPK 12:14:12 berwarna lebih hijau dibandingkan dengan perlakuan lainnya. Perlakuan pupuk $\mathrm{AB}$ mix menghasilkan bobot daun lebih besar dibandingkan dengan kedua perlakuan yang lain. Perlakuan jenis sumber hara tidak berpengaruh nyata terhadap bobot batang, dan bobot akar tanaman bayam.

Bobot Layak Pasar, Bobot Tidak Layak Pasar, Bobot Total, Bobot per Tanaman, Bobot per 4 Tanaman

Berdasarkan data Tabel 4 perlakuan jenis sumber hara tidak berpengaruh nyata terhadap hasil panen bobot layak pasar, bobot tidak layak pasar, dan bobot tanaman ${ }^{-1}$. Perlakuan pupuk memberikan pengaruh yang nyata terhadap bobot total dan bobot 4 tanaman $^{-1}$. Perlakuan pupuk AB mix menghasilkan tanaman bayam dengan bobot lebih tinggi dibandingkan dengan bobot perlakuan NPK 15:15:15 dan NPK 12:14:12.

Tabel 2. Pengaruh perlakuan jenis hara terhadap jumlah daun, lebar daun, dan panjang daun tanaman bayam

\begin{tabular}{|c|c|c|}
\hline \multirow{3}{*}{ Perlakuan } & \multicolumn{2}{|c|}{ Umur Tanaman $^{\mathrm{a}}$} \\
\hline & 1 (MST) & 2 (MST) \\
\hline & \multicolumn{2}{|c|}{ Jumlah daun } \\
\hline $\mathrm{AB}$ mix & 6.9 & $15.0 \mathrm{a}$ \\
\hline NPK $15: 15: 15$ & 6.9 & $11.4 b$ \\
\hline NPK 12:14:12 & 7.1 & $13.1 \mathrm{ab}$ \\
\hline \multirow[t]{2}{*}{ Uji F } & tn & $*$ \\
\hline & \multicolumn{2}{|c|}{ Lebar Daun $(\mathrm{cm})$} \\
\hline $\mathrm{AB} \operatorname{mix}$ & 4.32 & 8.18 \\
\hline NPK 15:15:15 & 4.33 & 7.51 \\
\hline NPK 12:14:12 & 4.34 & 7.56 \\
\hline \multirow[t]{2}{*}{ Uji F } & tn & tn \\
\hline & \multicolumn{2}{|c|}{ Panjang Daun $(\mathrm{cm})$} \\
\hline $\mathrm{AB}$ mix & 0.35 & 12.63 \\
\hline NPK $15: 15: 15$ & 0.29 & 11.64 \\
\hline NPK 12:14:12 & 0.32 & 12.15 \\
\hline Uji F & tn & tn \\
\hline \multicolumn{3}{|c|}{$\begin{aligned} & \text { Keterangan: }(*) \text { berpengaruh nyata pada taraf uji } 5 \% \\
&(\text { tn) tidak berpengaruh nyata pada tara } \\
& \text { uji a angka-angka yang diikuti huru } \\
& \text { yang sama pada kolom yang sama tida } \\
& \text { berbeda nyata menurut uji DMRT } 5 \% \\
& \text { MST }=\text { Minggu setelah tanam }\end{aligned}$} \\
\hline
\end{tabular}

Tabel 3. Pengaruh perlakuan jenis hara terhadap skor warna daun, bobot daun, bobot batang, dan bobot akar tanaman bayam

\begin{tabular}{lcccc}
\hline \multirow{2}{*}{ Perlakuan } & \multirow{2}{*}{ Skor Warna Daun } & \multicolumn{3}{c}{ Bobot Tanaman $^{-1}(\mathrm{~g})$} \\
\cline { 3 - 5 } & & Daun & Batang & Akar \\
\hline AB mix & $3.1 \mathrm{~b}$ & $13.17 \mathrm{a}$ & 9.00 & 2.67 \\
NPK 15:15:15 & $3.0 \mathrm{~b}$ & $8.67 \mathrm{~b}$ & 6.58 & 2.59 \\
NPK 12:14:12 & $3.5 \mathrm{a}$ & $9.42 \mathrm{~b}$ & 7.00 & 2.61 \\
Uji F & $*$ & $*$ & tn & tn \\
\hline Keterangan : (*) berpengaruh nyata pada taraf uji 5\%; (tn) tidak berpengaruh nyata pada taraf uji 5\%; ${ }^{\text {a } a n g k a-a n g k a}$ \\
\multicolumn{2}{r}{ yang diikuti huruf yang sama pada kolom yang sama tidak berbeda nyata menurut uji DMRT 5\% }
\end{tabular}

Tabel 4. Pengaruh perlakuan jenis hara terhadap bobot layak pasar, bobot tidak layak pasar, bobot total, bobot per tanaman, dan bobot per 4 tanaman bayam

\begin{tabular}{|c|c|c|c|c|c|}
\hline \multirow[b]{2}{*}{ Perlakuan } & \multicolumn{3}{|c|}{ Bobot 12 tanaman $(\mathrm{g})$} & \multirow{2}{*}{$\begin{array}{c}\text { Bobot } \\
\text { Tanaman }^{-1} \\
\text { (g) }\end{array}$} & \multirow{2}{*}{$\begin{array}{c}\text { Bobot } 4 \\
\operatorname{Tanaman}^{-1}(\mathrm{~g})\end{array}$} \\
\hline & $\begin{array}{c}\text { Bobot Layak } \\
\text { Pasar }\end{array}$ & $\begin{array}{l}\text { Bobot Tidak } \\
\text { Layak Pasar }\end{array}$ & $\begin{array}{c}\text { Bobot } \\
\text { Total }\end{array}$ & & \\
\hline $\mathrm{AB} \operatorname{mix}$ & 235.75 & 24.00 & $259.75 a$ & 21.65 & $86.58 \mathrm{a}$ \\
\hline NPK $15: 15: 15$ & 195.50 & 28.00 & $223.50 b$ & 18.63 & $74.50 \mathrm{~b}$ \\
\hline NPK 12:14:12 & 180.50 & 46.25 & $226.75 b$ & 18.90 & $75.58 b$ \\
\hline Uji F & tn & tn & $*$ & tn & $*$ \\
\hline
\end{tabular}




\section{Pakchoy (Brassica rapa cv Pakchoy) Tinggi Tanaman dan Diameter Batang}

Berdasarkan data Tabel 5 rata-rata tinggi tanaman dan diameter batang tanaman pakchoy 'Nauli' menunjukkan respon tidak berpengaruh nyata pada tinggi tanaman umur 1-4 MST dan diameter batang umur 1-2 MST. Perlakuan pupuk menunjukkan respon yang sangat nyata umur 3 MST dan nyata umur 4 MST pada diameter batang. Perlakuan pupuk AB mix terlihat berbeda nyata dengan pupuk NPK 12:14:12. Menurut penelitian iqbal (2006) pertumbuhan vegetatif setiap tanaman sangat dipengaruhi oleh komponen hara yang diberikan. Persentase $\mathrm{N}$ yang berbeda pada fase vegetatif tanaman menyebabkan tanaman tersebut mengalami perbedaan dalam proses pertumbuhannya.

\section{Jumlah Daun, Lebar Daun, Panjang Daun}

Perlakuan ketiga jenis sumber hara yang digunakan tidak berpengaruh nyata terhadap jumlah daun umur 1-2 MST, akan tetapi pada umur 3-4 MST perlakuan jenis sumber hara memberikan respon yang nyata (Tabel 6).

Tabel 5. Pengaruh perlakuan jenis hara terhadap tinggi tanaman, dan diameter batang tanaman pakchoy

\begin{tabular}{|c|c|c|c|c|}
\hline \multirow{3}{*}{ Perlakuan } & \multicolumn{4}{|c|}{ Umur Tanaman } \\
\hline & $\begin{array}{c}1 \\
(\mathrm{MST})\end{array}$ & $\begin{array}{c}2 \\
(\mathrm{MST})\end{array}$ & $\begin{array}{c}3 \\
(\mathrm{MST})\end{array}$ & $\begin{array}{c}4 \\
\text { (MST) }\end{array}$ \\
\hline & \multicolumn{4}{|c|}{ Tinggi Tanaman $(\mathrm{cm})$} \\
\hline $\mathrm{AB}$ mix & 2.99 & 3.89 & 4.77 & 5.44 \\
\hline $\begin{array}{l}\text { NPK } \\
15: 15: 15\end{array}$ & 3.23 & 4.04 & 4.69 & 5.13 \\
\hline $\begin{array}{l}\text { NPK } \\
12: 14: 12\end{array}$ & 2.92 & 3.81 & 4.54 & 5.27 \\
\hline \multirow[t]{2}{*}{ Uji F } & tn & tn & tn & tn \\
\hline & \multicolumn{4}{|c|}{ Diameter Batang $(\mathrm{cm})^{\mathrm{a}}$} \\
\hline $\mathrm{AB} \operatorname{mix}$ & 0.19 & 0.29 & $0.40 \mathrm{a}$ & $0.51 \mathrm{a}$ \\
\hline $\begin{array}{l}\text { NPK } \\
15: 15: 15\end{array}$ & 0.17 & 0.28 & $0.35 b$ & $0.45 \mathrm{ab}$ \\
\hline $\begin{array}{l}\text { NPK } \\
12: 14: 12\end{array}$ & 0.17 & 0.27 & $0.35 b$ & $0.41 b$ \\
\hline Uji F & tn & tn & $* *$ & $*$ \\
\hline Keterangan: & \multicolumn{4}{|c|}{$\begin{array}{l}\text { (*) berpengaruh nyata pada taraf uji } 5 \% \text {; } \\
(* *) \text { berpengaruh sangat nyata pada taraf } \\
\text { uji } 1 \% \text {; (tn) tidak berpengaruh nyata } \\
\text { pada taraf uji } 5 \% \text {; angka-angka yang } \\
\text { diikuti huruf yang sama pada kolom } \\
\text { yang sama tidak berbeda nyata menurut } \\
\text { uji DMRT } 5 \% \text {, MST = Minggu setelah } \\
\text { tanam }\end{array}$} \\
\hline
\end{tabular}

Tabel 6. Pengaruh perlakuan jenis hara terhadap jumlah daun, lebar daun, dan panjang daun tanaman pakchoy

\begin{tabular}{|c|c|c|c|c|}
\hline \multirow{3}{*}{ Perlakuan } & \multicolumn{4}{|c|}{ Umur Tanaman } \\
\hline & $\begin{array}{c}1 \\
(\mathrm{MST})\end{array}$ & $\begin{array}{c}2 \\
(\mathrm{MST})\end{array}$ & $\begin{array}{c}3 \\
(\mathrm{MST})\end{array}$ & $\begin{array}{c}4 \\
(\mathrm{MST})\end{array}$ \\
\hline & \multicolumn{4}{|c|}{ Jumlah Daun $^{\mathrm{a}}$} \\
\hline $\mathrm{AB}$ mix & 6.7 & 9.7 & $13.2 \mathrm{a}$ & $16.8 \mathrm{a}$ \\
\hline \multicolumn{5}{|l|}{ NPK } \\
\hline $15: 15: 15$ & 6.6 & 9.2 & $11.9 \mathrm{~b}$ & $14.1 \mathrm{~b}$ \\
\hline \multicolumn{5}{|l|}{ NPK } \\
\hline $12: 14: 12$ & 6.3 & 9.5 & $12.3 b$ & $14.9 \mathrm{~b}$ \\
\hline \multirow[t]{2}{*}{ Uji F } & tn & tn & $*$ & $*$ \\
\hline & \multicolumn{4}{|c|}{ Lebar Daun $(\mathrm{cm})$} \\
\hline $\mathrm{AB}$ mix & 3.04 & $4.58 \mathrm{a}$ & 5.16 & 5.43 \\
\hline \multicolumn{5}{|l|}{ NPK } \\
\hline $15: 15: 15$ & 3.06 & $4.56 a$ & 5.24 & 5.57 \\
\hline \multicolumn{5}{|l|}{ NPK } \\
\hline $12: 14: 12$ & 2.91 & $3.90 \mathrm{~b}$ & 4.48 & 4.78 \\
\hline \multirow[t]{2}{*}{ Uji F } & tn & $*$ & tn & tn \\
\hline & \multicolumn{4}{|c|}{ Panjang Daun $(\mathrm{cm})$} \\
\hline $\mathrm{AB}$ mix & 8.17 & $11.23 \mathrm{a}$ & 12.2 & 12.73 \\
\hline \multicolumn{5}{|l|}{ NPK } \\
\hline $15: 15: 15$ & 7.81 & $10.71 b$ & 12.16 & 12.58 \\
\hline \multicolumn{5}{|l|}{ NPK } \\
\hline $12: 14: 12$ & 7.59 & $10.15 b$ & 11.16 & 11.52 \\
\hline Uji F & tn & $*$ & tn & tn \\
\hline \multicolumn{5}{|c|}{$\begin{array}{r}\text { Keterangan : }(*) \text { berpengaruh nyata pada taraf uji 5\%; } \\
\text { (tn) tidak berpengaruh nyata pada taraf } \\
\text { uji 5\% a angka-angka yang diikuti huruf } \\
\text { yang sama pada kolom yang sama tidak } \\
\text { berbeda nyata menurut uji DMRT 5\%, } \\
\text { MST = Minggu setelah tanam }\end{array}$} \\
\hline
\end{tabular}

Perlakuan pupuk AB mix menghasilkan jumlah daun lebih banyak dibanding perlakuan lainnya. Perlakuan jenis sumber hara tidak berpengaruh nyata terhadap lebar daun dan panjang daun kecuali, pada umur 2 MST menunjukan respon yang nyata. Perlakuan pupuk NPK 12:14:12 menghasilkan lebar daun lebih kecil, sedangkan perlakuan pupuk $\mathrm{AB}$ mix menghasilkan panjang daun lebih panjang.

\section{Bobot per Tanaman, Bobot Layak Pasar, Bobot Tidak Layak Pasar, Bobot Total, Bobot per 4 Tanaman}

Tabel 7 menunjukkan bahwa peubah bobot per tanaman, bobot layak pasar, bobot tidak layak pasar, bobot total dan bobot per 4 tanaman sangat nyata dipengaruhi oleh perlakuan jenis sumber hara. Perlakuan dengan pupuk AB mix menghasilkan bobot tanaman ${ }^{-1}$, bobot layak pasar, bobot total, dan bobot 4 
tanaman $^{-1}$ lebih tinggi dibandingkan kedua perlakuan yang lain. Peubah bobot tidak layak pasar perlakuan pupuk $\mathrm{AB}$ mix memberikan hasil yang rendah dibanding perlakuan lainnya.

Bobot Daun, Bobot Batang, Bobot Akar, Skor Warna Daun

Peubah bobot daun sangat nyata dipengaruhi oleh perlakuan jenis sumber hara. Perlakuan dengan pupuk $\mathrm{AB}$ mix menghasilkan bobot daun lebih tinggi dibandingkan dengan kedua perlakuan lainnya. Peubah bobot batang dan bobot akar menunjukkan respon yang nyata terhadap perlakuan jenis sumber hara. Perlakuan dengan pupuk $\mathrm{AB}$ mix menghasilkan bobot batang dan bobot akar lebih tinggi dibandingkan kedua perlakuan lainnya. Perlakuan ketiga jenis sumber hara tidak berpengaruh nyata terhadap skor warna daun, Skor warna daun berkisar 3.1-3.5 menunjukkan bahwa warna daun pakchoy cukup hijau.

Selada (Lactuca sativa $\mathbf{L}$ )

Tinggi Tanaman dan Diameter Batang

Perlakuan jenis sumber hara yang digunakan tidak berpengaruh nyata terhadap tinggi tanaman selada umur 1-4 MST dan diameter batang umur 1-2 MST (Tabel 9). Pada umur 3-4 MST perlakuan jenis sumber hara menunjukkan pengaruh yang nyata pada peubah diameter batang. Perlakuan pupuk $\mathrm{AB}$ mix pada peubah diameter batang umur 4 MST berbeda nyata dengan pupuk NPK 12:14:12, tetapi perlakuan pupuk NPK 15:15:15 tidak berbeda nyata terhadap pupuk $\mathrm{AB}$ mix dan NPK 12:14:12.

\section{Jumlah Daun, Lebar Daun, Panjang Daun}

Tabel 10 menunjukkan bahwa perlakuan jenis sumber hara tidak berpengaruh nyata terhadap peubah jumlah daun selada. Perlakuan jenis sumber hara tidak berpengaruh nyata pada peubah lebar daun dan panjang daun selada kecuali, pada lebar daun umur 3 MST, dan panjang daun umur 2 MST perlakuan jenis sumber hara memberikan pengaruh yang nyata. Perlakuan NPK 12:14:12 menghasilkan lebar daun lebih tinggi, dan perlakuan pupuk $\mathrm{AB}$ mix menghasilkan panjang daun lebih panjang dibanding kedua perlakuan lainnya.

Tabel 7. Pengaruh perlakuan jenis hara terhadap bobot per tanaman, bobot layak pasar, bobot tidak layak pasar, bobot per 4 tanaman pakchoy

\begin{tabular}{|c|c|c|c|c|c|}
\hline \multirow[b]{2}{*}{ Perlakuan } & \multirow{2}{*}{$\begin{array}{c}\text { Bobot } \\
\text { Tanaman }^{-1} \\
(\mathrm{~g})^{\mathrm{a}}\end{array}$} & \multicolumn{3}{|c|}{ Bobot 12 tanaman $(\mathrm{g})$} & \multirow{2}{*}{$\begin{array}{c}\text { Bobot } 4 \\
\text { Tanaman }^{-1} \\
\text { (g) }\end{array}$} \\
\hline & & $\begin{array}{c}\text { Bobot Layak } \\
\text { Pasar }\end{array}$ & $\begin{array}{l}\text { Bobot Tidak } \\
\text { Layak Pasar }\end{array}$ & Bobot Total & \\
\hline $\mathrm{AB}$ mix & $46.06 \mathrm{a}$ & $465.75 \mathrm{a}$ & $87.00 \mathrm{~b}$ & $552.75 \mathrm{a}$ & $184.25 \mathrm{a}$ \\
\hline NPK 15:15:15 & $32.58 b$ & $81.50 \mathrm{~b}$ & $295.75 a$ & $377.25 b$ & $125.67 \mathrm{~b}$ \\
\hline NPK 12:14:12 & $28.67 b$ & $95.25 \mathrm{~b}$ & $248.75 \mathrm{a}$ & $344.00 \mathrm{~b}$ & $114.67 \mathrm{~b}$ \\
\hline Uji F & $* *$ & $* *$ & $* *$ & ** & ** \\
\hline
\end{tabular}

Keterangan: $(*)$ berpengaruh nyata pada taraf uji 5\%; (**) berpengaruh sangat nyata pada taraf uji 1\%; angka-angka yang diikuti huruf yang sama pada kolom yang sama tidak berbeda nyata menurut uji DMRT 5\%

Tabel 8. Pengaruh perlakuan jenis hara terhadap bobot daun, bobot batang, bobot akar, skor warna daun tanaman pakchoy

\begin{tabular}{lcccc}
\hline & \multicolumn{4}{c}{ Bobot Tanaman $^{-1}(\mathrm{~g})$} \\
\cline { 2 - 5 } Perlakuan & Daun $^{\mathrm{a}}$ & Batang & Akar & Skor Warna Daun \\
\hline AB mix & $52.00 \mathrm{a}$ & $2.08 \mathrm{a}$ & $2.49 \mathrm{a}$ & 3.1 \\
NPK 15:15:15 & $35.58 \mathrm{~b}$ & $1.17 \mathrm{~b}$ & $2.41 \mathrm{~b}$ & 3.1 \\
NPK 12:14:12 & $31.25 \mathrm{~b}$ & $1.08 \mathrm{~b}$ & $2.41 \mathrm{~b}$ & 3.5 \\
Uji F & $* *$ & $*$ & $*$ & tn \\
\hline
\end{tabular}

Keterangan: $(*)$ berpengaruh nyata pada taraf uji $5 \%$; (**) berpengaruh sangat nyata pada taraf uji $1 \%$; (tn) tidak berpengaruh nyata pada taraf uji 5\%; 'angka-angka yang diikuti huruf yang sama pada kolom yang sama tidaberbeda nyata menurut uji DMRT 5\% 
Tabel 9. Pengaruh perlakuan jenis hara terhadap tinggi tanaman dan diameter batang tanaman selada

\begin{tabular}{|c|c|c|c|c|}
\hline \multirow{3}{*}{ Perlakuan } & \multicolumn{4}{|c|}{ Umur Tanaman } \\
\hline & 1(MST) & 2(MST) & 3(MST) & 4(MST) \\
\hline & \multicolumn{4}{|c|}{ Tinggi Tanaman (cm) } \\
\hline $\mathrm{AB}$ mix & 2.64 & 6.61 & 9.18 & 15.21 \\
\hline NPK 15:15:15 & 2.18 & 5.67 & 8.75 & 14.90 \\
\hline NPK 12:14:12 & 2.44 & 4.92 & 7.41 & 13.54 \\
\hline \multirow[t]{2}{*}{ Uji F } & th & tn & tn & tn \\
\hline & \multicolumn{4}{|c|}{ Diameter Batang $(\mathrm{cm})^{\mathrm{a}}$} \\
\hline $\mathrm{AB}$ mix & 0.21 & 0.31 & $0.38 \mathrm{a}$ & $0.47 \mathrm{a}$ \\
\hline NPK 15:15:15 & 0.20 & 0.30 & $0.36 \mathrm{a}$ & $0.42 \mathrm{ab}$ \\
\hline NPK 12:14:12 & 0.19 & 0.26 & $0.32 b$ & $0.37 \mathrm{~b}$ \\
\hline Uji F & tn & tn & $*$ & $*$ \\
\hline
\end{tabular}

Tabel 10 Pengaruh perlakuan jenis hara terhadap jumlah daun, lebar daun, dan panjang daun selada

\begin{tabular}{|c|c|c|c|c|}
\hline \multirow{3}{*}{ Perlakuan } & \multicolumn{4}{|c|}{ Umur Tanaman } \\
\hline & $1(\mathrm{MST})$ & 2(MST) & $3(\mathrm{MST})$ & 4(MST) \\
\hline & \multicolumn{4}{|c|}{ Jumlah Daun } \\
\hline $\mathrm{AB}$ mix & 5.0 & 6.2 & 7.1 & 8.8 \\
\hline NPK $15: 15: 15$ & 4.8 & 7.2 & 8.5 & 9.0 \\
\hline NPK 12:14:12 & 4.6 & 6.6 & 7.6 & 8.6 \\
\hline \multirow[t]{2}{*}{ Uji F } & tn & tn & tn & tn \\
\hline & \multicolumn{4}{|c|}{ Lebar Daun $(\mathrm{cm})^{\mathrm{a}}$} \\
\hline $\mathrm{AB}$ mix & 3.48 & 4.73 & $4.96 \mathrm{~b}$ & 5.79 \\
\hline NPK $15: 15: 15$ & 3.17 & 4.18 & $5.09 \mathrm{ab}$ & 5.93 \\
\hline NPK 12:14:12 & 3.03 & 4.46 & $5.26 \mathrm{a}$ & 5.64 \\
\hline \multirow[t]{2}{*}{ Uji F } & tn & tn & $*$ & tn \\
\hline & \multicolumn{4}{|c|}{ Panjang Daun $(\mathrm{cm})$} \\
\hline $\mathrm{AB}$ mix & 7.69 & $10.13 \mathrm{a}$ & 10.48 & 11.75 \\
\hline NPK $15: 15: 15$ & 7.23 & $8.44 \mathrm{~b}$ & 10.26 & 12.09 \\
\hline NPK 12:14:12 & 6.96 & $8.84 b$ & 10.58 & 11.58 \\
\hline Uji F & tn & $*$ & tn & tn \\
\hline
\end{tabular}

\section{Bobot per Tanaman, Bobot Tidak Layak Pasar, Bobot Total, Bobot per 4 Tanaman}

Peubah bobot per tanaman, bobot tidak layak pasar, bobot total, dan bobot per 4 tanaman sangat nyata dipengaruhi oleh perlakuan ketiga jenis hara yang digunakan (Tabel 11). Perlakuan pupuk AB mix menghasilkan bobot tanaman ${ }^{-1}$ dan bobot 4 tanaman $^{-1}$ lebih tinggi dibanding perlakuan lainnya. Intensitas cahaya matahari yang tinggi dapat menekan pertumbuhan tinggi tanaman, sebaliknya apabila intensitas cahaya matahari rendah dapat menyebabkan ruas memanjang sampai batas tertentu dan menyebabkan tanaman mengalami etiolasi (Firmansyah et al., 2009). Susila (2006) menyatakan bahwa penggunaan pupuk daun dapat memperbaiki hasil panen, sehingga aplikasi pupuk dengan melakukan kombinasi $\mathrm{AB}$ mix melalui akar dengan pupuk melalui daun dapat digunakan untuk meningkatkan hasil dan kualitas tanaman selada. Kenyataannya penggunaan pupuk daun tidak cocok untuk pertumbuhan tanaman selada secara THST (Teknologi Hidroponik Sistem Terapung). Semua hasil panen tidak layak pasar. 
Tabel 11. Pengaruh perlakuan jenis hara terhadap bobot per tanaman, bobot per 4 tanaman, bobot tidak layak pasar, bobot total tanaman selada

\begin{tabular}{|c|c|c|c|c|}
\hline \multirow{2}{*}{ Perlakuan } & \multirow{2}{*}{$\begin{array}{c}\text { Bobot } \\
\operatorname{tanaman}^{-1}(\mathrm{~g})\end{array}$} & \multicolumn{2}{|c|}{ Bobot 12 tanaman $(\mathrm{g})^{\mathrm{a}}$} & \multirow{2}{*}{$\begin{array}{c}\text { Bobot } 4 \\
\operatorname{tanaman}^{-1}(\mathrm{~g})\end{array}$} \\
\hline & & Bobot tidak layak pasar & Bobot total & \\
\hline $\mathrm{AB}$ mix & $25.93 a$ & $311.15 \mathrm{a}$ & $311.15 \mathrm{a}$ & $103.72 \mathrm{a}$ \\
\hline NPK $15: 15: 15$ & $17.31 \mathrm{~b}$ & $203.45 b$ & $203.45 b$ & $67.82 \mathrm{~b}$ \\
\hline NPK 12:14:12 & $16.38 \mathrm{~b}$ & $180.43 b$ & $180.43 b$ & $60.14 b$ \\
\hline Uji F & $* *$ & $* *$ & $* *$ & $* *$ \\
\hline
\end{tabular}

Tabel 12. Pengaruh perlakuan jenis hara terhadap bobot daun, bobot batang, bobot akar tanaman selada

\begin{tabular}{lccc}
\hline \multirow{2}{*}{ Perlakuan } & \multicolumn{3}{c}{ Bobot per tanaman $(\mathrm{g})^{\mathrm{a}}$} \\
\cline { 2 - 4 } & Daun & Batang & Akar \\
\hline AB mix & $22.16 \mathrm{a}$ & 2.87 & $2.45 \mathrm{a}$ \\
NPK 15:15:15 & $14.51 \mathrm{~b}$ & 2.7 & $1.23 \mathrm{~b}$ \\
NPK 12:14:12 & $13.69 \mathrm{~b}$ & 2.67 & $0.88 \mathrm{~b}$ \\
Uji F & $* *$ & tn
\end{tabular}

Keterangan : (**) berpengaruh sangat nyata pada taraf uji 1\%; (tn) tidak berpengaruh nyata pada taraf uji 5\%; ${ }^{\text {angka- }}$ angka yang diikuti huruf yang sama pada kolom yang sama tidak berbeda nyata menurut uji DMRT 5\%

\section{Bobot Daun, Bobot Batang, Bobot Akar}

Berdasarkan data hasil panen bobot daun, bobot batang, bobot akar tanaman selada 'Belini' (Tabel 12), perlakuan jenis sumber hara berpengaruh sangat nyata terhadap peubah bobot daun dan bobot akar. Perlakuan pupuk $\mathrm{AB}$ mix menghasilkan bobot daun dan bobot akar lebih tinggi dibandingkan dengan kedua perlakuan yang lain. Perlakuan jenis sumber hara tidak berpengaruh nyata terhadap peubah bobot batang tanaman selada.

\section{KESIMPULAN}

Pengujian beberapa sumber hara memberikan hasil yang tidak berbeda terhadap pertumbuhan vegetatif tanaman bayam, pakchoy, dan selada akan tetapi, perlakuan pupuk $\mathrm{AB}$ mix memberikan hasil produksi yang lebih tinggi pada tanaman bayam, pakchoy, dan selada yaitu pada komponen hasil panen rata-rata bobot utuh tanaman ${ }^{-1}$ dan bobot layak pasar yaitu berturut-turut sebesar $21.65 \mathrm{~g}, 235.75 \mathrm{~g}$ tanaman bayam, $46.06 \mathrm{~g}$, $465.75 \mathrm{~g}$ tanaman pakchoy dan $25.93 \mathrm{~g}$ tanaman selada. Pada percobaan selada hasil panen tidak layak pasar. Perlakuan pupuk $A B$ mix memiliki hasil yang lebih baik dibandingkan dengan perlakuan pupuk NPK 15:15:15 dan NPK 12:14:12. Pupuk NPK 15:15:15 dan NPK 12:14:12 tidak dapat digunakan sebagai sumber hara pada budidaya bayam, pakchoy, dan selada secara hidroponik.

\section{DAFTAR PUSTAKA}

[BPS] Badan Pusat Statistik. 2012. Produksi sayuran Indonesia tahun 2010-2011. http://www.bps.go.id. [10 Desember 2012].

[BPS] Badan Pusat Statistik dan Direktorat Jenderal Hortikultura. 2012. Produktivitas sayuran di Indonesia tahun 2007- 2011. http://www.deptan.go.id/infoeksekutif/h orti/pdf-ATAP2011/Produkv-Sayuran. pdf. [10 Desember 2012].

Firmansyah. F., T.M. Anngo, A.M. Akyas. 2009. Pengaruh umur pindah tanam bibit dan populasi tanaman terhadap hasil dan kualitas sayuran pakcoy (Brassica campestris L. Chinensis group) yang ditanam dalam Naungan kasa di dataran medium. J Agricultura. 20(3): 216-224.

Iqbal, M. 2006. Penggunaan pupuk majemuk sebagai sumber hara pada budidaya bayam secara hidroponik dengan tiga cara fertigasi. Skripsi. Institut Pertanian Bogor. Bogor. 
Parks, S., C. Murray. 2011. Leafy Asean Vegetables and Their Nutrion in Hydroponics. State of New South Wales. Australian.

Ramadiani, F.T., A.D. Susila. 2014. Sumber dan frekuensi aplikasi larutan hara sebagai pengganti $\mathrm{AB}$ mix pada budidaya sayuran daun secara hidroponik. J. Hort Indonesia. 5(1): 3646.

Resh, H.M. 2004. Hydroponic Food Production $6^{\text {th }}$ Edition: A Definitife Guide Book for The Advance Home Gardener and The
Comercial Hydroponic Grower. New Concept Pr. New Jersey (US).

Susila, A.D. 2006. Fertigasi pada Budidaya Tanaman Sayuran di dalam Greenhouse. Direktorat Jenderal Hortikultura. Bandung.

Tellez, T., F.C.G. Merino. 2012. Nutrient Solutions For Hydroponic Systems. A. Toshiki, editor. Cina: InTech.

Utama, H.S., S.M. Isa, A. Indragunawan. 2006. Perancangan dan implementasi sistem optimalisasi pemeliharaan tanaman hidroponik. J Teknik Elektro. 8(1): 1-4. 